\title{
TRUST AND MANAGEMENT CONTROL SYSTEM: A STUDY ON META- SINTHETIC INTERACTIONS
}

\author{
Patricia Villa Costa Vaz* \\ patriciavilla00@gmail.com \\ Márcia Maria dos Santos Bortolocci Espejo** \\ marciabortolocci@gmail.com \\ *Universidade Federal do Paraná - PR / Brasil \\ **Universidade Federal do Mato Grosso do Sul - MS / Brasil
}

\section{http://dx.doi.org/10.1590/1413-2311.07316.62764}

Recebido em 04/03/2016

Aprovado em 02/05/2017

Disponibilizado em 31/05/2017

Avaliado pelo distema "double blind review"

Revista Eletrônica de Administração

Editora-chefe: Andrea Oltramari

ISSN 1413-2311 (versão "on line")

Editada pela Escola de Administração da Universidade Federal do Rio Grande do Sul

Periodicidade: Quadrimestral

Sistema requerido: Adobe Acrobat Reader

\begin{abstract}
Management accounting has been associated to the institutionalization of trust inside organizations. Trust allows the implementation of systems which grant freedom to choose without trying to process more information about the world than it ought to be done. (TOMKINS, 2001). Regarding such aspects, this paper questions: how have previous studies been relating trust and Management Control Systems (MCS) towards reaching organizational objectives? To achieve this, we object to examine the role of trust in Management Control System, and its relation with organizational objectives, according to Hoon's (2014) methodology, which allow the construction of a theory based on primary case studies. On developing the methodology four causal networks have been examined on selected studies: institutions, Management Control Systems, trust and organizational objectives. The institutions represent the effective background of the case studies, specially as a series of habits, rules, routines and procedures; the approaches regarding management control systems include budget and performance evaluation; in relation to trust, previous studies have
\end{abstract}


primarily discussed it through contract, communication and competence approaches; and, as to organizational objectives, changes on current systems, focus on performance and business risk reduction are tackled. Feedback, however, was dealt with after achieving objectives, when management incorporates trust on personnel relationships - the primary step towards goals and objectives.

Key words: Trust. Case study. Meta-synthesis. Management Control Systems.

\title{
CONFIANÇA E SISTEMAS DE CONTROLE GERENCIAL: UM ESTUDO SOBRE AS RELAÇÕES META-SINTÉTICAS
}

\begin{abstract}
RESUMO
A contabilidade gerencial tem sido associada à institucionalização de confiança dentro de uma organização. A confiança permite adotar esquemas que fornecem liberdade de escolha, sem tentar processar mais informações sobre o mundo do que se é capaz de fazer (TOMKINS, 2001). Considerando estes aspectos, o presente estudo questiona: de que maneira os estudos anteriores vêm relacionando a confiança com o Sistema de Controle Gerencial (SCG) para o alcance dos objetivos organizacionais? Para tanto, objetiva-se examinar o papel da confiança no Sistema do Controle Gerencial, e sua relação com os objetivos organizacionais, conforme a metodologia da meta-síntese de Hoon (2014), que visa a construção de uma teoria a partir de estudos de caso qualitativos primários. Na elaboração dos passos da metodologia, depreenderam-se quatro redes causais nos estudos selecionados: instituições, Sistema de Controle Gerencial, confiança e objetivos organizacionais. As instituições representam o contexto de realização dos estudos de caso, especialmente sua caracterização como uma sucessão de hábitos, regras, rotinas e procedimentos. As abordagens sobre o Sistema de Controle Gerencial incluem a avaliação de desempenho e o orçamento. Com relação à confiança os estudos anteriores discutiram, sobretudo, as vertentes contratual, comunicativa e de competência desta variável. Quanto aos objetivos organizacionais, os estudos discutem aspectos como mudança no sistema vigente, o foco no desempenho e na redução do risco do negócio. Ao final da análise, o item de feedback se apresentou nos estudos como a etapa após o alcance dos objetivos, na qual a gestão interioriza a confiança nas relações pessoais, passando esta a ser parte importante no alcance das metas e objetivos.
\end{abstract}


Palavras chave: Confiança. Estudos de caso. Meta-síntese. Sistemas de Controle Gerencial.

\title{
CONFIANZA Y SISTEMAS DE CONTROL DE GESTIÓN: UN ESTUDIO SOBRE LAS RELACIONES META-SINTÉTICAS
}

\begin{abstract}
RESUMEN
La contabilidad de gestión se ha relacionado con la institucionalización de confianza dentro de una organización. La confianza permite adoptar esquemas que proporcionan la libertad de elección sin tratar de procesar más información sobre el mundo que es capaz de hacer (TOMKINS, 2001). Teniendo en cuenta estos aspectos, este estudio se pregunta: ¿cómo los estudios anteriores han relacionado la confianza con el Sistema de Control de Gestión (SCG) para la consecución de los objetivos de la organización? Por lo tanto, el objetivo es examinar el papel de la confianza en el Sistema de Control de Gestión, y su relación con los objetivos de la organización, de acuerdo con la metodología de meta-síntesis de Hoon (2014), que tiene por objeto la construcción de una teoría a partir de estudios de caso cualitativos primarios. En la preparación de los pasos de la metodología, aparecen cuatro redes causales en los estudios seleccionados: instituciones, Sistema de Control de Gestión, la confianza y los objetivos de la organización. Instituciones representan el contexto de la realización de estudios de casos, especialmente su caracterización como una sucesión de hábitos, normas, rutinas y procedimientos. Los enfoques para el Sistema de Control de Gestión incluyen la evaluación del desempeño y el presupuesto. Con respecto a la confianza, los estudios anteriores discuten los aspectos contractuales, la comunicación y la competencia de esta variable. En cuanto a los objetivos de la organización, los estudios analizan temas como el cambio en el sistema actual, el rendimiento y la reducción en el riesgo del negocio. Después del análisis, el elemento de feedback presenta en el estudio como el paso después de la consecución de los objetivos, en los que la gestión internaliza la confianza en las relaciones personales, permitiendo que ésta sea una parte importante en el logro de las metas y objetivos.
\end{abstract}

Palabras Clave: Confianza. Estudios de caso. Meta-síntesis. Sistemas de Control de Gestión.

\section{INTRODUCTION}


The information of management controls comprises a range of data towards company management which, somehow, ought to be able to use this specific language; such "data becomes information as long as it allows users to act towards changes in current status which not always occurs" (AMORIM, 2007, p. 20). According to Neu (1991), accounting professionals hold a privileged position in occidental societies for they are trusted as able to professionally convey valuable and accountable knowledge. According to Palmer, Ziegenfuss and Pinsker (2004) accounting professional required skills have recently been strongly upheld to public and regulation higher standards due to economic crisis and scandals. Discussions have been occurring spotlighting accounting professions and information values (MCMILLAN, 2004); ranging from communication, problem-solving, personal and interpersonal skills, to information technology, computer, accounting and business acumen (MCMILLAN, 2004).

Therefore, some authors (JOHANSSON; BALDVINSDOTTIR, 2003; BARDY, 2006; LANGEVIN; MENDOZA, 2013) have been discussing management accounting regarding trust institutionalization within an organization. Tomkins (2001) defines trust as the adoption of a belief for one of the parts, in a relationship in which the other part shall not act against it, where this belief is acted upon without neither hindrance nor doubt - even without further information about the first part's actions. Trust is defined as a three-legged construct: contract, competence and communication (REINA; REINA, 2007); being the first related to people skill and competence acknowledgement; the second to upholding contracts as previously agreed; and the third to information disclosure. Accounting has been attempting the trust construct regarding evaluator-evaluatee relationship towards relations with Management Control System and organizational objectives (ROSS, 1994; JOHANSSON; BALDVINSDOTTIR, 2003; SMITH, 2005; BUSCO; RICCABONI; SCAPENS, 2006; LAVARDA; FELIU; PALANCA, 2009; BRUNO, 2013).

In accordance to these aspects, this study enquires: how have previous studies been relating trust and Management Control Systems (MCS) towards reaching organizational objectives? In order to do so, Hoon's (2014) meta-synthesis methodology shall be used to examine previous qualitative case studies whenever trust is related to Management Control Systems and from organizational objectives ranges.

This paper is justified by considering trust allows the implementation of systems which grant freedom to choose without trying to process more information about the world than it ought to be done. (TOMKINS, 2001). Therefore, to trust someone allows acting as if 
there were less uncertainty - albeit those uncertainties have not been actually diminished. Smith (2005) defines trust as a belief management accounting ought to work towards organization best scenario. High interdependence levels promote a reliable and entrusting environment at all times, making opportunity behaviors not cost-effective to partners (GULATI; SYTCH, 2007). As shared knowledge decreases, common expectations raise trust importance (NEU, 1991). What makes accounting reliable is a consistent behavior throughout long times, specially towards honesty, transparency, coherence, competence and care about people, their say and feelings (SMITH, 2005).

As a theoretical contribution, this paper suggests a theoretical framework on joint analysis of Management Control Systems and ranges of trust towards organizational objectives, able to serve as basis on further studies towards its application and validation in a plethora of institutional environments. As practical contribution, it sheds new light within organization environments: it emphasizes trust roles as most relevant towards components of Management Control Systems and organizational objectives.

It is divided as follows: The role of trust in Management Control Systems, main subject; steps from Hoon (2014) methodology herein; meta-synthesis data analysis - item 4; followed by final considerations and references.

\section{THEORETICAL BASIS}

\subsection{The role of trust in Management Control Systems}

According to Tomkins (2001), to trust someone allows acting as if there were less uncertainties - albeit those uncertainties have not been actually diminished. Trust, therefore, is omnipresent: a paramount social landmark. If anyone wishes to understand relationships, trust limits ought to be discussed (TOMKINS, 2001).

According to Rousseau, Sitkin, Burt and Camerer (1998, p. 395),

Trust is a psychological state comprising the intention to accept vulnerability based upon positive expectations of the intentions or behavior of other. (...) Because risk and interdependence are necessary conditions for trust, variations in these factors over the course of a relationship between parties can alter both the level and, potentially, the form that trust takes.

These authors evaluate previous studies to their articles and have found three major steps in organizations: trust as a building construct, a stable one, or a declining one - and the 
according trust for each step - not the inter-relation to the other steps (ROUSSEAU et al., 1998).

Regarding conceptualization, trust may be seen as independent (cause), dependent (effect), or interaction (moderator): the first model relates to studies towards economy and transaction cost savings; the second to Japanese company historical analysis, inasmuch as institutional accordance and sociologic perspective - for trust relies on aspects from the counterpart; and, the third, to interpersonal behavior in organizations and social arrangements based on social psychology and micro-organizational behavior theories (ROUSSEAU et al., 1998).

Regarding different construct choices, Rousseau et al. (1998) state trust is not a control mechanism, but a substitute for control which reflects a positive attitude towards others' motives; therefore trust may be based on calculations, relational or institution-based.

The first form of trust is a rational choice, a characteristic of economical theory exchange interactions: trust emerges when the trustor acknowledges the trustee intends to act beneficially. Calculative based trust derives from restrictions and from the reliability of information regarding intentions or competence of other parts. Relational trust arises from repeated interactions over time between trustor and trustee, being themselves enough to the latter to constitute its very basis. And, finally, institution-based trust may ease the way to formulate the first two ones. Previous restrictions may also promote trust for trusting someone with a reputation allows, primarily, relation structuring.

Regarding types of trust, Reina and Reina (2007) affirm the transactional trust, both reciprocal and created incrementally, may be of competence, contractual or communication trust. Competence trust refers to ability, to skilful decision-making and to searching for new inputs to improve it further. Contractual trust relates to trust in people, characterized by expectation management, establishing boundaries, assigning wisely, encouraging mutuallyserving intentions, keeping agreements, and performing consistently. Differently, communication trust comprises disclosure, information sharing - upheld whenever the parts speak truthfully, admit mistakes, supply and receive feedback, and, keep confidentiality.

Previous studies regarding trust and Management Control Systems are divided in three primary fronts.

The first one regards the theoretical studies on trust in accounting - specially in Management Control Systems. Mayer, Davis and Schoorman (1995) have developed a model of organizational trust which shows the higher the trustor's propensity to trust the, greater the 
administrator's trust prior to the availability of information about the trustee. Tomkins (2001) has examined the fundamental concepts related to information needs - specially accounting ones. Smith (2005) has highlighted matters concerning necessary department and worker issues when developing trust in accounting. Busco, Riccaboni and Scapens (2006) explored how management accounting systems may be related to learning processes and organizational culture for change, and how they should be used to identify reliable solutions when organizational crises arise. Baldvinsdottir, Hagber, Johansson, Jonäll and Marton (2011) have provided a literary revision regarding the accounting and trust nexus. And, Sabatier (2014) has discussed subjects expediting manager trust building; he suggested to managers hints on concentrating their efforts to build trust.

The second front deals with empirical studies analyzing trust between leaderships and followers. Ross (1994) has analyzed that, within high levels of trust, the usage of a specific evaluation style with budget or profit limitations may result in lower tension at work than the usage of a non-accounting performance evaluation. Johansson and Baldvinsdottir (2003) have confirmed performance evaluations derive from trust, as well as evaluation task production and reproduction, along with all parts concerning, the evaluator, the evaluated, and, the accountant. Ferrante (2006) examined the innovative practice of accounting information sharing towards workers promote benefits in the relation among employers and employees, with an increase on trust and performance. Hartman and Slapnicar (2009) have confirmed the worker's trust in the hierarchical superior relies on the formality of performance evaluation processes, mediated by management justice and feedback perceptions. Lavarda, Feliu and Palanca (2009) have analyzed the incorporating factors which positively influenced MCS institutionalization were the knowledge and skill of agents involved in the changing process, computer resources, personnel background and willingness, low outsourced MCS specialist participation, worker incentive system, trust relationships, and, planning processes.

The third process also deals with empirical studies, this time concerning trust in interorganizational trust. Cuganesan (2007) has investigated how the formal trust control works on the dynamics of collaborations, analyzing relations between formal controls (contracts and accounting controls) and trust. Free (2008) has analyzed how such practices influence on building trust in UK retail segment. Vosselman and Van der Meer-Kooistra (2009) has debated trust aids both control production as control addition - control may decrease trust level in situations where it exceeds necessary compensations to negative legitimate behavioral expectations. Meira, Kartalis, Tsamenyi and Cullen (2010) have stated there are not many 
studies regarding trust development processes, and, they suggested further lines of study towards the contract nexus between accounting and trust, especially when considering most inter-company relations are contract-based.

After having stated the relation among trust concepts and Management Control System, the next item presents the methodology of Hoon (2014), the meta-synthesis, utilized herein.

\section{METODOLOGY}

The methodology of Hoon (2014), the meta-synthesis, here utilized purports to the construction of a theory from primary qualitative case studies, defined according to specific criteria (HOON, 2014). Eight steps have been stated in order to build it, according to Chart 1:

\begin{tabular}{|l|l|}
\multicolumn{2}{|c|}{ Chart 1 - Meta-synthesis steps } \\
\hline Steps & \multicolumn{1}{c|}{ Analytic objective } \\
\hline 1 & Research question framing \\
\hline 2 & Relevant research location \\
\hline 3 & Exclusion criteria \\
\hline 4 & Data extraction and codification \\
\hline 5 & Specific case analysis \\
\hline 6 & Cross study synthesis \\
\hline 7 & Theory construction based on meta-synthesis \\
\hline 8 & Discussion \\
\hline
\end{tabular}

According to Hoon (2014), the first step is the framing of the research issue towards suiting meta-synthesis methodology within adequate context. The question of specific research should aid concerning variables in becoming operational besides the primary study separation.

The second step concerns the location of relevant researches, with articles that will become a part of the meta-synthesis. In order to locate studies within research accordance an extensive bibliographic, enquire ought to be carried out in order to exclude irrelevant information.

The third step regards exclusion criteria specification towards specifying which studies have methods, theoretical basis, focus and standards within research accordance. This step ensures study viability and reliability. The following step is the analysis of selected metasynthesis papers. 
The fourth step is data extraction and codification, that is, a thorough examination of all selected papers, codifying study characteristics and presenting basic insights according to this research in question.

The fifth step comprises specific case analyses, identifying the sequence of variables which had been found in each case study and had been considered more relevant to research objective development.

The next step is the cross-level synthesis of all selected papers, that is, the gathering of such papers within a meta-causal network. In this step, the sequence of variables obtained in each case specific analysis - proceeding from the previous step - is accumulated to generate a pattern.

The two last steps comprise theory construction from meta-synthesis and discussion: the first one identifies concepts which enlighten interdependences among presented variables; the second one comprises a final process reflection, followed by discussions regarding metasynthesis results and potential limitations.

In the next topic each step of Hoon's (2014) meta-synthesis will be explored aiming to answer the research question of the present study.

\section{DATA ANALYSIS AND DISCUSSION - META-SYNTHESIS}

\subsection{Step 1 - Research question framing}

In this first step, the problem and the phenomenon to be investigated have been defined. Theoretically, there had been no consensus regarding trust roles in Management Control System for the development of meta-synthesis.

In order to do so, attempts have been made to comprehend the relationship between trust and Management Control System, limiting study range to organizational trust and enquiring: how previous studies have been relating trust with Management Control System towards organizational trust? Thus, according to meta-synthesis, the primary concerning studies have been selected.

\subsection{Step 2 - Relevant research location}

In this second step, the identification of relevant articles towards meta-synthesis has been carried out through Web of Science website main collection - Social Science, restricted to the terms "management control system*" 'and" "trust", without date limitation, resulting in 24 articles - 22 periodicals; 2 congress - as shown in Chart 2. 
Chart 2 - Articles from step 2

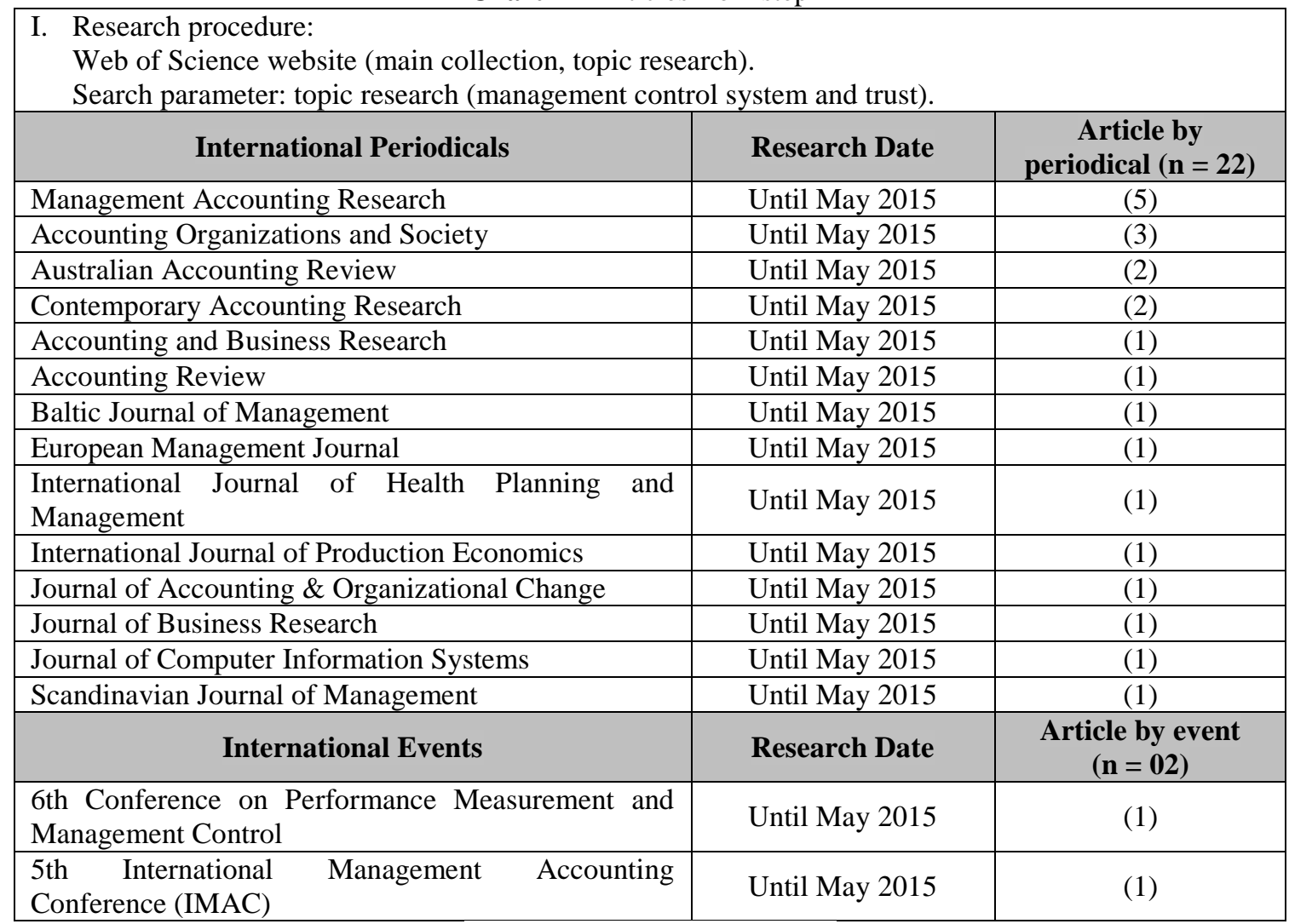

Source: produced by the author

Web of Science website search resulted in 14 international periodicals, within various strata, mostly from accounting and management; while the two congress ones focused on Management Control System and trust.

\subsection{Step 3 - Exclusion criteria}

The third step regards exclusion criteria specification towards specifying which studies were not relevant for the current research development. After first paper selection, analysis showed 17 from those 24 did not fall within investigation range, for: (i) used methodology did not comprise case studies (six articles); (ii) article discussion fell on different approaches (seven articles); and, (iii) some articles comprised downloadable abstracts only (four articles) - despite further attempts to research them in ulterior, restrict-access, databases. Appendix A lists references and reasons for dismissal.

Chart 3 lists excluded results and reasons for doing so.

Chart 3 - Step 3 exclusion criteria

\begin{tabular}{l|l|l} 
Criterias & Excluded Result Reasons & Excluded references
\end{tabular}




\begin{tabular}{|c|c|c|}
\hline $\begin{array}{lc}\text { (i) Case } & \text { study } \\
\text { (qualitative) } & \end{array}$ & $\begin{array}{l}\text { Used methodology did not } \\
\text { comprise case studies, therefore } \\
\text { excluded }\end{array}$ & $\begin{array}{l}\text { - Greenberg; Greenberg and Mahenthiran (2008) } \\
\text { experimental study; } \\
\text { - Pappas and Flaherty (2008) quantitative study; } \\
\text { - Hartmann and Slapnicar (2009) quantitative study; } \\
\text { - Pettersen (2011): quantitative study; } \\
\text { - Kilfoyle; Richardson and MacDonald (2013) } \\
\text { theoretical study on accounting vocabulary; } \\
\text { - Langevin and Mendoza (2013) the methodology } \\
\text { wasn't case study. }\end{array}$ \\
\hline $\begin{array}{lr}\text { (ii) } & \text { Investigation } \\
\text { range } & \text { within } \\
\text { research } & \\
\text { accordance } & \end{array}$ & $\begin{array}{l}\text { discussion } \\
\text { range, }\end{array}$ & $\begin{array}{l}\text { - Free (2007) analyses interpersonal relations in } \\
\text { supply chains; } \\
\text { - Van der Meer-Koistra and Scapens (2008) explore } \\
\text { the nature of lateral relations and develop structures } \\
\text { to define elements from governance package for } \\
\text { those relations; } \\
\text { - Homburg and Stebel (2009) analyse the key } \\
\text { factors of contractual clauses among professional } \\
\text { service companies and their clients; } \\
\text { - Sundin; Brown; Wakefield and Ranganathan } \\
\text { (2009) analyse the Management Control System in } \\
\text { non-governmental companies; } \\
\text { - Appuhami; Perera and Perera (2011) discuss a } \\
\text { control model within public-private partnerships; } \\
\text { - Caker and Siverbo (2014) analyse strategic } \\
\text { alliances in lieu of interactions among } \\
\text { organisational structure, social ideological control } \\
\text { and technocratic control; } \\
\text { - Vazquez; Rodriguez and Kekale (2014) } \\
\text { investigate established distribution channels and the } \\
\text { roles adopted by control systems over changes on } \\
\text { the distribution network. }\end{array}$ \\
\hline $\begin{array}{l}\text { (iii) Downloadable } \\
\text { studies }\end{array}$ & $\begin{array}{l}\text { Non-downloadable } \\
\text { therefore excluded }\end{array}$ & $\begin{array}{l}\text { - Rowe (2004); } \\
\text { - Zin (2009); } \\
\text { - Flores et al. (2011); } \\
\text { - Rooney and Cuganesan (2013). }\end{array}$ \\
\hline
\end{tabular}

Source: produced by the author

According to Chart 3 and first criterion within, quantitative, theoretical and experimental studies, as well as those outside case study methodology have been excluded from the sample. The second criterion, investigation range excluded seven papers not dealing with trust in Management Control System. The third criterion - downloadable studies - excluded four more. Therefore, seven articles comprised meta-synthesis final sample, and have been analyzed regarding quality, as follows.

\subsection{Step 4 - Data extraction and codification}

Data have been extracted and codified towards meta-synthesis selected study evidence categorization. According to Hoon (2014), this stage allows the researcher autonomy to define parameters to be used in study codification, herein his model has been adapted according to answer quality towards investigated matters, as shown in Chart 4. 
Chart 4 - Outline for Step 4 codification

\begin{tabular}{|c|c|}
\hline \multicolumn{2}{|r|}{ General Study Details } \\
\hline 1 & Writer \\
\hline 2 & Title \\
\hline 3 & Periodical / Congress \\
\hline 4 & Publication date \\
\hline 5 & Type of study \\
\hline \multicolumn{2}{|r|}{ Writer's objective } \\
\hline 6 & General objective \\
\hline 7 & Research proposition \\
\hline 8 & Contributions \\
\hline \multicolumn{2}{|r|}{$\begin{array}{l}\text { Theoretical framing } \\
\end{array}$} \\
\hline 9 & How does the paper discuss Management Control System trust issues? \\
\hline 10 & How does the paper discuss trust aspects? \\
\hline 11 & Concepts / understanding Management Control System; \\
\hline 12 & Concepts / understanding trust; \\
\hline \multicolumn{2}{|r|}{ Study Context } \\
\hline 13 & Country \\
\hline 14 & Industry / sector \\
\hline 15 & Research context \\
\hline 16 & Research location \\
\hline 17 & Research outline \\
\hline \multicolumn{2}{|r|}{ Metodology } \\
\hline 18 & Research project \\
\hline 19 & Approach \\
\hline 20 & Analysis unit \\
\hline 21 & Number of investigated cases \\
\hline 22 & Sampling strategy \\
\hline \multicolumn{2}{|r|}{ Data and source collection technique } \\
\hline 23 & Time and data collection sequence \\
\hline 24 & Data collection techniques \\
\hline 25 & Data source \\
\hline 26 & Data amount / validity \\
\hline 27 & Data management techniques \\
\hline \multicolumn{2}{|r|}{ Data analysis approach } \\
\hline 28 & Data analysis methods \\
\hline 29 & Analysis techniques \\
\hline \multicolumn{2}{|r|}{ Perspectives } \\
\hline 30 & Main conclusions evidenced by summaries, introductions and conclusions hereupon \\
\hline 31 & Obtained events, factors or patterns regarding trust in Management Control System \\
\hline 32 & Trust effects on Management Control System \\
\hline 33 & Environmental conditions \\
\hline 34 & Conceptual model or frame visualisation \\
\hline \multicolumn{2}{|r|}{ Discussion } \\
\hline 35 & Main result discussion \\
\hline \multicolumn{2}{|r|}{$\begin{array}{r}\text { Contribution } \\
\end{array}$} \\
\hline 36 & Contribution to general accounting; \\
\hline 37 & Contribution to further areas \\
\hline \multicolumn{2}{|r|}{ Limitations } \\
\hline 38 & General limitations \\
\hline 39 & Study relevance for investigated study \\
\hline 40 & Study validity \\
\hline 41 & Information inconsistency \\
\hline 42 & Additional comments \\
\hline
\end{tabular}


According to Hoon (2014), the objective of those Chart 4 open questions is to assure insights to researchers; hereto the final outline has been based on these 42 extraction and codification items.

\subsection{Step 5 -Specific case analysis}

In this step, every remaining article has been mapped towards variable identification of granting causal network development and specific comprehension of each case analysis, as shown in Figure 1.

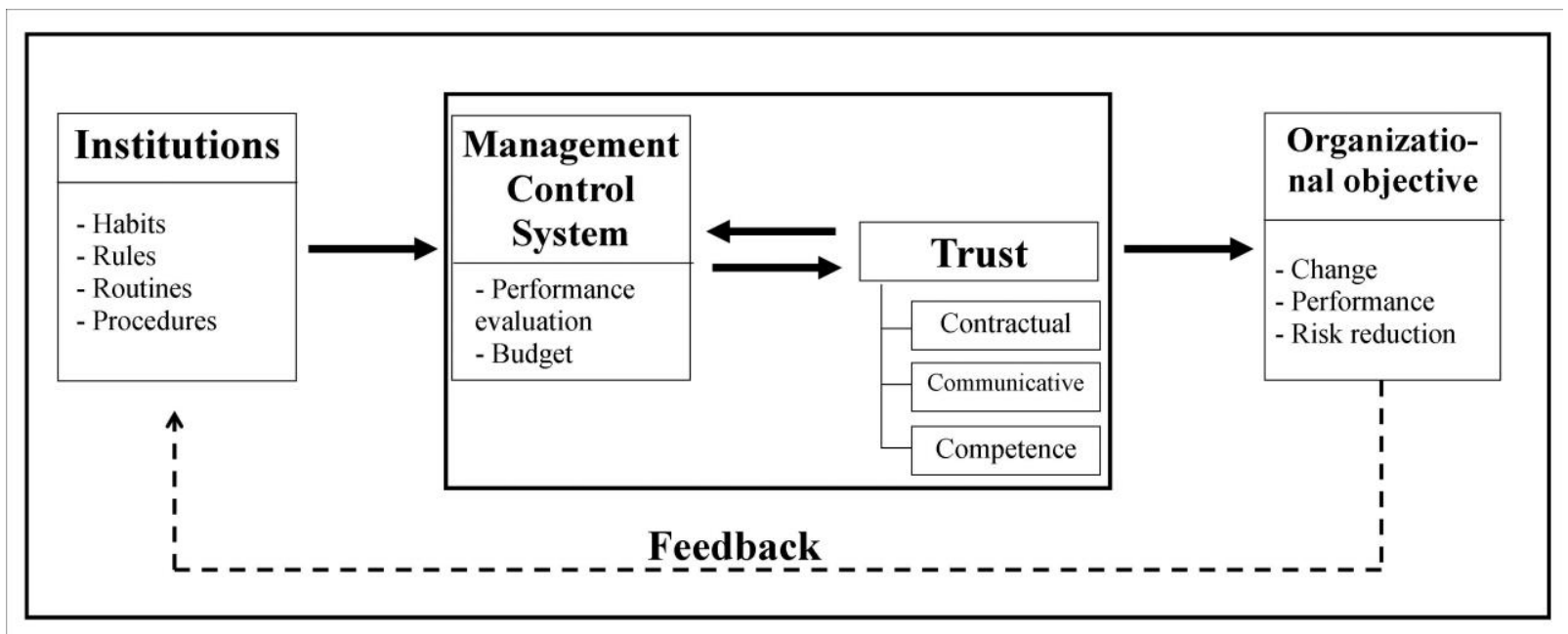

Figure 1 - Step 5 Meta-causal network

Source: produced by the author

According to figure 1, four causal networks have been identified: institutions, Management Control System, trust and organizational objective. The institution represents the implementation context of case studies, specially its characterization as a sequence of habits, rules, routines and procedures. Approaches regarding Management Control System include primarily, performance evaluation and budget. As far as trust is concerned, it has been discussed - specially through contractual, communication and competence perspectives. Regarding organizational objectives, studies discuss aspects as changes in the current system, focus on performance and business risk reduction. The feedback risk, however, at the bottom of the picture, was presented as a phase after reaching the objectives - in which management incorporates the interpersonal relationship trust, an important factor towards achieving goals and objectives. 
Bidirectionality between Management Control System and trust should also be stressed, according to Cuganesan (2007, p. 122), due to continuous usage of control based on outcome and behavior - maybe seen as not enough justification to the costs in doing so - and, also resulting in a management control reduce usage in the long run. Whereas, if initial trust level expectations dwindle, larger control dependences may occur - due to its apparent objectivity in representing performance levels as mere perception of participant behaviors. Neutrality or control - and its quantifiable nature - independence makes it a consistent device on personnel management, for if it is based on processes (as management control) and reinforce or uphold trust, MCS may become less dependent from future personal interaction. Otherwise, if the mechanisms decrease trust levels, MCS shall become more dependent from future personal interaction.

\subsection{Step 6 - Cross study synthesis}

This stage aims to analyze case identified variables jointly, towards a meta-causal network. Approaches of studies towards Figure 2 mapping/organization are shown in Chart 5. 
Chart 5 - Variables and their classifications

\begin{tabular}{|c|c|c|c|c|c|c|}
\hline \multirow{3}{*}{ Author / Year } & \multirow{3}{*}{ Institutions } & \multirow{3}{*}{ Management Control System } & \multirow{2}{*}{\multicolumn{3}{|c|}{ Trust }} & \multirow{3}{*}{ Organizational objectives } \\
\hline & & & & & & \\
\hline & & & Contractual & Communicative & Competence & \\
\hline $\begin{array}{l}\text { 1. Johansson } \\
\text { and } \\
\text { Baldvinsdottir } \\
\text { (2003) }\end{array}$ & $\begin{array}{l}\text { They use 'Old Institutional } \\
\text { Economics' concepts, } \\
\text { where institutions are the } \\
\text { social articulation of human } \\
\text { activity, created and re- } \\
\text { created by thoughts and } \\
\text { habits - in this case: } \\
\text { performance evaluation. }\end{array}$ & $\begin{array}{l}\text { They analyze performance } \\
\text { evaluation processes } \\
\text { considering management } \\
\text { accounting contributes to ways } \\
\text { of acting based on habits, } \\
\text { routines and rules, shaping daily } \\
\text { organizational processes. }\end{array}$ & \multicolumn{3}{|c|}{$\begin{array}{l}\text { They do not use such classification although they consider contractual } \\
\text { trust, for they discuss the notion that in order to win evaluator's trust; the } \\
\text { evaluated one has to accept control on early stages, and, once trust is } \\
\text { proven, active control should be substituted by discreet monitoring - so as } \\
\text { to not violate such trust; otherwise, if the evaluated one has not deserved it, } \\
\text { control should be re-introduced. }\end{array}$} & \begin{tabular}{lr}
\multicolumn{2}{l}{ Performance evaluation as } \\
a tool to assure \\
improvement & on \\
organizational & \\
performance. &
\end{tabular} \\
\hline $\begin{array}{l}2 . \quad \text { Busco, } \\
\text { Riccaboni and } \\
\text { Scapens }(2006)\end{array}$ & $\begin{array}{l}\text { Set of rules (formal } \\
\text { statement of procedures) } \\
\text { and routines (ongoing } \\
\text { practices), linked to } \\
\text { production and re- } \\
\text { production of knowledge. }\end{array}$ & $\begin{array}{l}\text { They use terminology from } \\
\text { Management Control System } \\
\text { (they analyze company } \\
\text { accounting and finance sector } \\
\text { restructuring). }\end{array}$ & \multicolumn{3}{|c|}{$\begin{array}{l}\text { They do not use such classification although they consider trust as } \\
\text { mechanism able to reduce uncertainty in interaction contexts and to } \\
\text { promote proper organizational system working through social behaviors, } \\
\text { therefore regarding contractual trust. }\end{array}$} & $\begin{array}{l}\text { Efficacy on individual un- } \\
\text { learning processes and } \\
\text { changes in organizational } \\
\text { culture. }\end{array}$ \\
\hline $\begin{array}{l}\text { 3. Cuganesan } \\
(2007)\end{array}$ & $\begin{array}{l}\text { Contract set. He analyses } \\
\text { relations within a supplier } \\
\text { network. }\end{array}$ & $\begin{array}{l}\text { He analyses formal control } \\
\text { mechanism subgroups as } \\
\text { contracts and accounting } \\
\text { controls (result control - } \\
\text { budget, or behavior - rules and } \\
\text { regulations). }\end{array}$ & $\begin{array}{l}\text { It may be positively } \\
\text { influenced by } \\
\text { contracts, being } \\
\text { accounting controls } \\
\text { able to reinforce or to } \\
\text { uphold it, reducing } \\
\text { performance measure } \\
\text { strictness through } \\
\text { time. }\end{array}$ & $\begin{array}{l}\text { Contracts } r \begin{array}{l}\text { and } \\
\text { accounting }\end{array} \text { controls } \\
\text { influence negatively } \\
\text { whenever under strict } \\
\text { application. }\end{array}$ & $\begin{array}{l}\text { Accounting controls } \\
\text { may reinforce it or } \\
\text { uphold it, reducing } \\
\text { performance measure } \\
\text { strictness through time. }\end{array}$ & $\begin{array}{l}\text { Performance improvement } \\
\text { through cost reduction } \\
\text { within supplier network. }\end{array}$ \\
\hline $\begin{array}{l}\text { 4. Emsley and } \\
\text { Kidon (2007) }\end{array}$ & $\begin{array}{l}\text { Contract set. They verify } \\
\text { existent relations in } \\
\text { establishing a joint venture. }\end{array}$ & $\begin{array}{l}\text { They verify operational and } \\
\text { executive controls, such as } \\
\text { output and behavior controls, } \\
\text { generated through joint venture } \\
\text { establishment. }\end{array}$ & It is not mentioned. & $\begin{array}{l}\text { Social control trust and } \\
\text { small contact among } \\
\text { joint venture } \\
\text { governance committee } \\
\text { executives resulted in } \\
\text { low information level: } \\
\text { trust was slowly } \\
\text { developed. }\end{array}$ & $\begin{array}{l}\text { Output, behavior and } \\
\text { social controls within } \\
\text { operational level } \\
\text { workers produced a } \\
\text { high amount of } \\
\text { information, increasing } \\
\text { joint venture } \\
\text { governance committee } \\
\text { trust over them. }\end{array}$ & $\begin{array}{l}\text { Efficacy on organizational } \\
\text { changes (joint venture). }\end{array}$ \\
\hline $\begin{array}{l}\text { 5. Langfield- } \\
\text { Smith (2008) }\end{array}$ & $\begin{array}{lr}\text { Uses concepts from TCE - } \\
\text { Transaction } \\
\text { Economics, where the }\end{array}$ & $\begin{array}{l}\text { Considers Management Control } \\
\text { as a set, composed by relations } \\
\text { between governance structure, }\end{array}$ & It is not mentioned. & $\begin{array}{l}\text { Activities developed in } \mathrm{t} \\
\text { during the interim } \\
\text { communication and com }\end{array}$ & $\begin{array}{l}\text { e pre-alliance phase and } \\
\text { liance increased both } \\
\text { etence trust. }\end{array}$ & $\begin{array}{lr}\text { Manager's } & \text { perception } \\
\text { towards relational risks } \\
\text { reduction } & \text { and } \\
\end{array}$ \\
\hline
\end{tabular}

REAd | Porto Alegre - Edição 86 - N 1 - Janeiro / Abril 2017 - p. 156-178 


\begin{tabular}{|c|c|c|c|c|c|c|}
\hline & $\begin{array}{ll}\text { manager adopts certain } \\
\text { governance strategies } & \text { to } \\
\text { minimize costs } & \text { in } \\
\text { collaborative alliances. } & \end{array}$ & $\begin{array}{l}\text { processes towards trust } \\
\text { development, risk mitigation } \\
\text { and control mechanisms } \\
\text { (behavior, output and social } \\
\text { controls). }\end{array}$ & & & & $\begin{array}{l}\text { improvements on alliance } \\
\text { performance. }\end{array}$ \\
\hline $\begin{array}{l}6 . \quad \text { Vélez; } \\
\text { Sánches and } \\
\text { Álvarez-Dardet } \\
(2008)\end{array}$ & $\begin{array}{l}\text { Relations among partner } \\
\text { companies towards } \\
\text { achieving desirable or pre- } \\
\text { defined results. }\end{array}$ & $\begin{array}{l}\text { Focus on Management Control } \\
\text { System main functions: } \\
\text { Monitoring (rewarding and } \\
\text { performance measuring) and } \\
\text { Coordination (workload, } \\
\text { specialization, knowledge and } \\
\text { skill assignment). }\end{array}$ & It is not mentioned. & \multicolumn{2}{|c|}{$\begin{array}{l}\text { In an evolving open relation, Management } \\
\text { Control Systems are able to build trust even when } \\
\text { it has already been established. High trust enables } \\
\text { success to further partners to cooperation, and, } \\
\text { demanding higher cooperation trust levels. } \\
\text { Formal controls enable partner reliability } \\
\text { perception improvements towards these two } \\
\text { varieties of trust. }\end{array}$} & $\begin{array}{l}\text { Improvements on company } \\
\text { relations considered as } \\
\text { ability to solve problems } \\
\text { and to manage } \\
\text { interdependencies, } \\
\text { improving satisfaction and } \\
\text { joint results. }\end{array}$ \\
\hline $\begin{array}{l}\text { 7. Pernot and } \\
\text { Roodhooft } \\
(2014)\end{array}$ & $\begin{array}{l}\text { Contingency } \\
\text { relationships } \quad \text { between } \\
\text { suppliers and } \\
\text { manufacturers }- \text { subject to } \\
\text { relational and performance } \\
\text { risks. }\end{array}$ & $\begin{array}{l}\text { Set of formal and informal } \\
\text { controls towards strategic } \\
\text { objective decision-making; they } \\
\text { analyze cases where formal } \\
\text { controls seem not to overload } \\
\text { operational difficulties. }\end{array}$ & $\begin{array}{l}\text { Improvement when } \\
\text { assuring that actions } \\
\text { were contractually } \\
\text { sound. }\end{array}$ & $\begin{array}{lr}\text { Improvement } & \text { on } \\
\text { sharing principles and } \\
\text { regulations. Mutual } \\
\text { willingness } \quad \text { is } \\
\text { necessary towards } \\
\text { organizational bonding. }\end{array}$ & $\begin{array}{l}\text { Improvement on } \\
\text { quality result and target } \\
\text { reaching due to } \\
\text { previous performance } \\
\text { and reputed provider } \\
\text { choices, delegating } \\
\text { competence. }\end{array}$ & $\begin{array}{l}\text { Risk reduction and } \\
\text { performance improvement } \\
\text { on manufacturer and } \\
\text { supplier relations. }\end{array}$ \\
\hline
\end{tabular}

Source: produced by the author 


\subsection{Step 7 - Building Theory from meta-synthesis}

Considering previous steps, this paper demonstrates researches regarding Management Control System trust range within organizational objectives towards system changes, connecting trust among parts as means to their implementation. As far as trust is concerned, the selected articles hereinbefore are divided in: contractual, communication and competence trust.

Such evidences unfold as thus: trust among parts is related to Management Control System towards cooperation in reaching pre-determined organizational objectives.

\subsection{Step 8 - Discussion}

At this last stage, limits concerning primary study heterogeneity and guidelines towards meta-synthesis performing must be evidenced. The present paper examines qualitative case studies towards contexts within trust and Management Control Systems, limited by the number of investigated papers - initially: 24; finally analyzed: 7 - albeit enough to contribute to the Management Control field. Once trust directly influences Management Control System usefulness, further investigations may yet be developed towards empirical verification of the theoretical framework suggested hereby.

This meta-synthesis reaches beyond recent studies, considering its methodology offers empirical consolidation well-founded on intense study search strategy of periodicals and national and international - congress papers regarding Management Control System and trust. Therefore, the meta-synthesis objective is the analysis of constructions, the main variables, and previous case study relations to obtain new theories and to improve existent ones (Hoon, 2014). Thus, the meta-synthesis based on qualitative case studies regarding a specific theme presents extensive synthetic potential.

\section{FINAL CONSIDERATIONS}

This paper has had, as objective, the application of Hoon's (2014) meta-synthesis methodology to examine how trust had been related to Management Control System in qualitative case studies previously published, as well as construct relation with organizational objectives. Such methodology allows theory constructions through primary qualitative case studies, defined according to criteria and set of steps: eight have herewith been developed, and four causal networks - institutions, Management Control System, trust, and, organizational objectives. 
Institutions represent case studies context, specially its characterization as a succession of habits, rules, routines and procedures; approaches on Management Control System include performance evaluation and budget; Regarding trust, its perspective (contractual, communication and competence) have been studied; and, towards organizational objectives, aspects such as changes in current system, performance focus and business risk reductions have been covered. Feedback, however, reached after achieving objectives, incorporates personal relation trust - an important step to reach goals.

Such evidences unfold as thus: trust among parts is related to Management Control System towards cooperation in reaching pre-determined organizational objectives.

As theoretical contribution, this study suggests a framework to analyze jointly Management Control Systems and the perspectives of trust, towards organizational objectives; such model may uphold future studies and be applied and validated in a plethora of institution environments. As a practical contribution, it sheds new light within organization environments: it emphasizes trust roles as most relevant towards components of Management Control Systems and organizational objectives.

A suggestion to additional studies is an analysis of trust acknowledge within all organization levels - allowing wider perception of Management Control System aspects as policies, procedures and other administrative control - and to validate this theoretical model in a plethora of institutions, furthering debates regarding relations between trust and Management Control System.

\section{REFERENCES}

AMORIM, A. D. G. A mediação da informação contábil sob a ótica da ciência da informação. 2007. Tese (Doutorado em Ciência da Informação) - Universidade de São Paulo, São Paulo, 2007.

APPUHAMI, R.; PERERA, S.; PERERA, H. Management Controls in Public-Private Partnerships: An Analytical Framework. Australian Accounting Review, Hoboken, v. 21, n. 1, p. 64-79, 2011.

BALDVINSDOTTIR, G. et al. Accounting research and trust: a literature review.

Qualitative Research in Accounting \& Management, Bingley, v. 8, n. 4, p. 382-424, 2011.

BARDY, R. Management control in a business network: new challenges for accounting. Qualitative Research in Accounting \& Management, Bingley, v. 3, n. 2, p. 161-181, 2006.

BRUNO, M. L. Confiança nas relações entre líderes e liderados. 2013. Tese (Doutorado em Contabilidade) - Universidade de São Paulo, São Paulo, 2013. 
BUSCO, C.; RICCABONI, A.; SCAPENS, R. W. Trust for accounting and accounting for trust. Management Accounting Research, Amsterdam, v. 17, n. 1, p. 11-41, 2006.

CAKER, M.; SIVERBO, S. Strategic alignment in decentralized organizations - The case of Svenska Handelsbanken. Scandinavian Journal of Management, Amsterdam, v. 30, n. 2, p. 149-162, 2014.

CUGANESAN, S. Accounting, contracts and trust in supply relationships. Journal of Accounting \& Organizational Change, Bingley, v. 3, n. 2, p. 104 - 125, 2007.

EMSLEY, D.; KIDON, F. The relationship between trust and control in international joint ventures: Evidence from the airline industry. Contemporary Accounting Research, Hoboken, v. 24, n. 3, p. 829-858, 2007.

FERRANTE, C. J. Innovative sharing: shared accounting information as a facilitator of trust and performance. Journal of Engineering and technology management, Amsterdam, v. 23, p. 54-63, 2006.

FLOREZ, R. et al. The role of management control systems on inter-organisational efficiency: an analysis of export performance. In: CONFERENCE ON PERFORMANCE MEASUREMENT AND MANAGEMENT CONTROL, 6., 2012, Nice. Proceedings... Nice, France: EIASM, 2012.

FREE, C. Supply-chain accounting practices in the UK retail sector: Enabling or coercing collaboration? Contemporary Accounting Research, Hoboken, v. 24, n. 3, p. 897-933, 2007.

GREENBERG, R. H.; GREENBERG, P. S.; MAHENTHIRAN, S. Virtual transfer price negotiations: unintended interactions with incentive systems. Journal of Computer Information Systems, Abingdon, v. 49, n. 2, p. 18-25, 2008.

GULATI, R.; SYTCH, M. Dependence Asymmetry and Joint Dependence in Interorganizational Relationships: Effects of Embeddedness on a Manufacturer's Performance in Procurement Relationships. Administrative Science Quarterly, Thousand Oaks, v. 52, p. 32-69, 2007.

HARTMANN, F.; SLAPNICAR, S. How formal performance evaluation affects trust between superior and subordinate managers. Accounting, Organizations and Society, Amsterdam, v. 34, n. 6/7, p. 722-737, 2009.

HOMBURG, C.; STEBEL, P. Determinants of contract terms for professional services. Management Accounting Research, Amsterdam, v. 20, n. 2, p. 129-145, 2009.

HOON, C. Meta-synthesis of qualitative case studies: an approach to the building. Organizational Research Methods, Thousand Oaks, v. 16, n. 4, p. 522-556, 2014.

JOHANSSON, I. L.; BALDVINSDOTTIR, G. Accounting for trust: some empirical evidence. Management Accounting Research, Amsterdam, v. 14, n. 3, p. 219-234, 2003. 
KILFOYLE, E.; RICHARDSON, A. J.; MACDONALD, L. D. Vernacular accountings: Bridging the cognitive and the social in the analysis of employee-generated accounting systems. Accounting Organizations and Society, Amsterdam, v. 38, n. 5, p. 382-396, 2013.

LANGEVIN, P.; MENDOZA, C. How can management control system fairness reduce managers' unethical behaviours? European Management Journal, Amsterdam, v. 31, n. 3, p. 209-222, 2013.

LANGFIELD-SMITH, K. The relations between transactional characteristics, trust and risk in the start-up phase of a collaborative alliance. Management Accounting Research, Amsterdam, v. 19, n. 4, p. 344-364, 2008.

LAVARDA, C. E. F.; FELIU, V. M. R.; PALANCA, M. B. La Interiorización del Cambio de un Sistema Contable de Gestión en la Pequeña Empresa. Revista Contabilidade \& Finanças, São Paulo, v. 20, n. 51, p. 101-115, 2009.

MAYER, R. C.; DAVIS, J. H.; SCHOORMAN, F. D. An Integrative Model of Organizational Trust. The Academy of Management Review, Briarcliff Manor, v. 20, n. 3, p. 709-734, 1995.

MCMILLAN, K. P. Trust and the virtues: a solution to the accounting scandals? Critical Perspectives on Accounting, Amsterdam, v. 15, n. 6-7, p. 943-953, 2004.

MEIRA, J. et al. Management controls and inter-firm relationships: a review. Journal of Accounting \& Organizational Change, Bingley, v. 6, n. 1, p. 149-169, 2010.

NEU, D. Trust, impression management and the public accounting profession. Critical Perspectives on Accounting, Amsterdam, v. 2, n. 3, p. 295-313, 1991.

PALMER, K. N.; ZIEGENFUSS, D. E.; PINSKER, R. E. International knowledge, skills, and abilities of auditors/accountants. Managerial Auditing Journal, Bingley, v. 19, n. 7, p. 889-896, 2004.

PAPPAS, J. M.; FLAHERTY, K. E. The effect of trust on customer contact personnel strategic behavior and sales performance in a service environment. Journal of Business Research, Amsterdam, v. 61, n. 9, p. 894-902, 2008.

PERNOT, E.; ROODHOOFT, F. The impact of inter-organizational management control systems on performance: A retrospective case study of an automotive supplier relationship. International Journal of Production Economics, Amsterdam, v. 158, p. 156-170, dec. 2014.

PETTERSEN, I. J. Trust-based or performance-based management-a study of employment contracting in hospitals. International Journal of Health Planning and Management, Hoboken, v. 26, n. 1, p. 18-38, 2011.

REINA, D. L.; REINA, M. L. Building Susteinable Trust. Od Practitioner, Saint Paul, v. 39, n. 1, p. 36-41, 2007. 
ROONEY, J.; CUGANESAN, S. The control dynamics of outsourcing involving an earlystage firm. Accounting and Business Research, Abingdon, v. 43, n. 5, p. 506-529, 2013.

ROSS, A. Trust as a moderator of the effect of performance evaluation style on job-related tension: a research note. Accounting, Organizations and Society, Amsterdam, v. 19, n. 7, p. 629-635, 1994.

ROUSSEAU, D. M. et al. Not so different after all: a cross-discipline view of trust. Academy of Management Review, Briarcliff Manor, v. 23, n. 3, p. 393-404, 1998.

ROWE, C. The effect of accounting report structure and team structure on performance in cross-functional teams. Accounting Review, Lakewood Ranch, v. 79, n. 4, 1153-1180, 2004.

SABATIER, M. As a leader are you trustworthy? Building trust to transform team working. Development and Learning in Organizations: An International Journal, Bingley, v. 28, n. 5, p. 3-5, 2014.

SMITH, G. How to achieve organizational trust within an accounting department. Managerial Auditing Journal, Bingley, v. 20, n. 5, p. 520-523, 2005.

SUNDIN, H. et al. Management Control Systems in a Non-Enterprise Network: The Greenhouse Gas Protocol Initiative. Australian Accounting Review, Hoboken, v. 19, n. 2, p. 93-102, 2009.

TOMKINS, C. Interdependencies, trust and information in relationships, alliances and networks. Accounting, Organizations and Society, Amsterdam, v. 26, n. 2, p. 161-191, 2001.

VAN DER MEER-KOOISTRA, J.; SCAPENS, R. W. The governance of lateral relations between and within organisations. Management Accounting Research, Amsterdam, v. 19, n. 4, p. 365-384, 2008.

VAZQUEZ, J. M. S.; RODRIGUEZ, G. C.; KEKALE, T. The role of control systems in partner selection/evaluation processes in established distribution channels. Baltic Journal of Management, Bingley, v. 9, n. 4, p. 426-445, 2014.

VELEZ, M. L.; SANCHEZ, J. M.; ALVAREZ-DARDET, C. Management control systems as inter-organizational trust builders in evolving relationships: Evidence from a longitudinal case study. Accounting Organizations and Society, Amsterdam, v. 33, n. 7-8, p. 968-994, 2008 .

VOSSELMAN, E.; VAN DER MEER-KOOISTRA, J. Accounting for control and trust building in interfirm transactional relationships. Accounting, Organizations and Society, Amsterdam, v. 34, n. 2, p. 267-283, 2009.

ZIN, R. M. Management Control Systems Of A Building Construction Project. Bangi: Univ Kebangsaan Malaysia. In: INTERNATIONAL MANAGEMENT ACCOUNTING CONFERENCE (IMAC), 5., Kuala Lumpur. Proceedings... Kuala Lumpur, Malaysia: 
Universidade Kebangsaan Malaysia, 2009.

REAd | Porto Alegre - Edição 86 - N 1 - Janeiro / Abril 2017 - p. 156 - 178 


\section{APPENDIX A}

\begin{tabular}{|c|c|c|c|c|}
\hline No. & Author / Year & International Periodics & Status & Justification \\
\hline 1 & Appuhami; Perera and Perera (2011) & Australian Accounting Review & Excluded & Different range \\
\hline 2 & Busco; Riccaboni and Scapens (2006) & Management Accounting Research & Meta-synthesis & - \\
\hline 3 & Caker and Siverbo (2014) & Scandinavian Journal of Management & Excluded & Different range \\
\hline 4 & Cuganesan (2007) & Journal of Accounting \& Organizational Change & Meta-synthesis & - \\
\hline 5 & Emsley and Kidon (2007) & Contemporary Accounting Research & Meta-synthesis & - \\
\hline 6 & Florez et al. (2012) & 6th Conference on Performance Measur. and Manag. Control & Excluded & $\begin{array}{l}\text { Downloadable } \\
\text { only }\end{array}$ \\
\hline 7 & Free $(2007)$ & Contemporary Accounting Research & Excluded & Different range \\
\hline 8 & $\begin{array}{l}\text { Greenberg; Greenberg and Mahenthiran } \\
\text { (2008) }\end{array}$ & Journal of Computer Information Systems & Excluded & Experimental study \\
\hline 9 & Hartman and Slapnicar (2009) & Accounting, Organizations and Society & Excluded & Quantitative study \\
\hline 10 & Homburg and Stebel (2009) & Management Accounting Research & Excluded & Different range \\
\hline 11 & Johansson and Baldvinsdottir (2003) & Management Accounting Research & Meta-synthesis & - \\
\hline 12 & Kilfoyle; Richardson and MacDonald (2013) & Accounting, Organizations and Society & Excluded & Theoretical study \\
\hline 13 & Langevin and Mendoza (2013) & European Management Journal & Excluded & No case study \\
\hline 14 & Langfield-Smith (2008) & Management Accounting Research & Meta-synthesis & - \\
\hline 15 & Pappas and Flaherty (2008) & Journal of Business Research & Excluded & Quantitative study \\
\hline 16 & Pernot and Roodhooft (2014) & International Journal of Production Economics & Meta-synthesis & - \\
\hline 17 & Pettersen (2011) International & Journal of Health Planning and Management & Excluded & Quantitative study \\
\hline 18 & Rooney and Cuganesan (2013) & Accounting and Business Research & Excluded & $\begin{array}{l}\text { Downloadable summary } \\
\text { only }\end{array}$ \\
\hline 19 & Rowe (2004) & Accounting Review & Excluded & $\begin{array}{l}\text { Downloadable } \\
\text { only }\end{array}$ \\
\hline 20 & Sundin et al. (2009) & Australian Accounting Review & Excluded & Different range \\
\hline 21 & Van der Meer-Kooistra and Scapens (2008) & Management Accounting Research & Excluded & Different range \\
\hline 22 & Vazquez; Rodriguez and Kekale (2014) & Baltic Journal of Management & Excluded & Different range \\
\hline 23 & Velez; Sanchez and Alvarez-Dardet (2008) & Accounting, Organizations and Society & Meta-synthesis & - \\
\hline 24 & Zin (2009) & V International Management Accounting Conference & Excluded & $\begin{array}{l}\text { Downloadable } \\
\text { only }\end{array}$ \\
\hline
\end{tabular}

REAd | Porto Alegre - Edição 86 - N 1 - Janeiro / Abril 2017 - p. 156 - 178 